\title{
Still Waiting: Labor, Revolution, and the Struggle for Social Justice in Egypt
}

\author{
Hanan Sabea \\ American University in Cairo
}

In his first televised address as prime minister on March 2, 2014, Ibrahim Mehleb reiterated what has become a familiar term of state rhetoric used to contain labor unrest, widely referred to as "the wheel of production" ("agalat el-intag) discourse. The true meaning of the "wheel of production" iteration was expressed in Mehleb's call on "Egyptians to help rebuild the nation and halt strikes and protests." ${ }^{1}$ When representatives of the state-or state-allied political actors, including some labor unions - proclaim that the "wheel of production must turn" in response to strikes and other labor demonstrations, they are suggesting that the protesters are behaving selfishly, in their own economic interests. For laborers to make demands for better wages and working conditions during a time of national crisis is presented to the public as a threat to economic stability and national security that is harmful to all Egyptians. Ironically, though not unexpectedly, in the same address Mehleb pledged to address many of the basic demands raised by protesting workers: a decent standard of living, the even distribution of resources, the rooting out of corruption, and institutional reform of the public sector-all while maintaining workers' rights. Although state agents' rhetorical commitment to decent standards of living and social and economic rights is not novel, the simultaneous conjuring of the "wheel of production" to halt protests has a more recent history occasioned by the last three years of revolutionary transformations.

It has been well documented that workers' protests long preceded the events of January 25, 2011 (the first day of mass protests leading to the fall of Hosni Mubarek), which are best exemplified by the series of Mahalla strikes ${ }^{2}$ that began in $2008 .^{3}$ In fact, "according to the Land Center for Human Rights, the number of labor protests in Egypt rose from 222 in 2006 to 756 in 2007 and exceeded 700 in 2009." ${ }^{4}$ Still, the events of 2011 left their mark on the demands and aspirations of the labor movement and the forms of protest it employed as well as the expanse, scope, and networks to which it was connected and within which its protests unfolded. First, the spectrum of what comprised the labor and workers' movement experienced a broad expansion to include not only the claims of organized labor and workers within established sectors, but also the issues of precarity and vulnerability that marked the lives of both workers and those formally classified as "unemployed." Redefining who was considered a "worker" and bringing together groups of laboring men, women, and children - who previously had not been seen as having much in common-around demands for a decent quality of life were key elements of 
the reformulation of the labor question. Thus, we see the emergence of street vendors, street children, taxi and microbus drivers, and casual agricultural workers, among others, as agents of equal standing with industrial laborers, raising their demands for the rights to a decent living, work, and remuneration. These demands were summed up in the 2011 Revolution's chants for bread, freedom, dignity, and social justice.

Second, the street and other forms of public space became critical sites of contestation in an effort not only to claim them for the purpose of debate and protest, but, just as importantly, to challenge the continuous wave of privatization that has swept Egypt over the last several decades. Workers protesting for better wages, including civil servants, state employees, and unskilled laborers at factories, were no longer limited to the boundaries and the confines of their workplaces. Rather, protesting workers became a familiar sight in the heart of Cairo, primarily at the doorsteps of the cabinet building and the parliament. Among their ranks during sit-ins were street vendors, street children, and masses of the so-called "unemployed"-people previously thought to inhabit a space outside the category of "worker."

Third, while labor-specific demands were expressed, broader public and collective aspirations were central to the calls for social change and political transformation. Primary among these were calls to end corruption among political and economic elites wherever they were positioned in the national imaginary - at factories, firms, state offices, police stations, and invisible networks controlling trade and the circulation of commodities and services. Equally important were aspirations and demands for better living and working conditions, political representation, the end of privatization, and increased equity in the distribution of national resources and the wealth they produce.

Finally, alliances between laboring men, women, and children, on the one hand, and a burgeoning sector of independent campaigns and organizational forms (such as the April 6 movement, the Egyptian Center for Economic and Social Rights [ECESR], the Association for Freedom of Thought and Expression [AFTE], and the Egyptian Initiative for Personal Rights [EIPR]) on the other, made it possible to imagine alternatives to classic organizational structures, tactics of struggle, and targets of demands for change. Thus, the cooperative movements in Argentina and the indignados (outraged) movement in Spain proffered models for rethinking courses of action and strategies for struggle. Local campaigns like that of the Kadeh youth movement ${ }^{5}$ suggested $^{-}$ alternatives to traditional forms of labor organizing.

Initially the "wheel of production" iteration was deployed in condemnation of workers' "sectorial demands" (mataleb fe'aweyya), which were packaged as individual, divisive, egotistic special interests, harmful to the "common good" during the transitional period of revolutionary transformation and the rule of the Supreme Council of Armed Forces (2011-2012). Coupled with such statements was a discursive depiction of workers, among other protesters, as thugs (baltageyya), counterrevolutionaries (thawra modada), and handmaidens of external forces-always ambiguously framed, yet generally understood to 
include the United States, Israel, Iran, and some Arab countries opposed to stability in Egypt - that aimed to destabilize the country. A call for a "return to normalcy" proliferated as a public narrative aiming to erect a façade of stability over turbulent processes of change. The rapidly shifting political and social terrain in Egypt, combined with the unrelenting desire on the part of a variety of political and social interests, especially those allied with the old Mubarak regime, to contain all forms of contentious politics, led to a security agenda to deal with the so-called unrest. Securitization and the policing of society merged with a shift in discursive productions from sectorial demands to the "wheel of production" rhetoric, as propagated by state agents-particularly cabinet members - and popularized by media outlets, both private and state-owned. While certain demands by labor resonated with government and business agendasfor instance, the revisiting of labor laws; the formation of independent syndicates representing various categories of workers, from women agricultural workers to street vendors, creative arts producers, taxi drivers, and farmers; and the court's nullification of the Tanta Flax company's privatization - the repressive machinery of state and capital also moved to break up (and eliminate) the potential for structural transformations and change embedded within these challenges to the status quo. By April 2013 it was reported that 4,500 factories had closed down, resulting in the dismissal or layoff of thousands of workers. ${ }^{6}$ Rising costs of raw materials, the increased cost of living, curfews, deteriorating environmental conditions, alarming food insecurity patterns, increased precarity in the provision of services-most apparent in road blocks, traffic jams, garbage collection, power cuts, and fuel shortages - and a continually widening gap between elites and the laboring poor, have all culminated not only in the growth of both protests and violent repression, but also in the rising tide of irregular (or illegal) migration and in the loss of life at sea, cycles of attacks on Egyptian workers in both North Africa and Europe, the closing of borders, and crackdown on mobility.

In the wake of the removal of President Mohamad Morsi in July 2013, state violence against any form of demonstration, labor protests included, reached its peak, this time in the name of the "fight against terrorism." By January 2014, despite systematic promises to do so, the cabinet again reneged on its commitment to raise the national minimum wage, resulting in a new and massive wave of labor protests between January and March 2014. This explosion of protests was met with a particularly aggressive deployment of violence and repression, culminating in the criminalization of protests and strikes in workplaces, the detention (and disappearance) of key labor organizers, and the social demonization of protesting workers as traitors to the nation at a time of national emergency. According to a report by the independent statistical database and portal Wiki Thawra released on May 25, 2014, a total of 41,163 individuals had been arrested and prosecuted since July 2013. During those ten short months, the report details,

36,478 people were either arrested or have otherwise been prosecuted legally as a result of participation in political events, 376 of which face trials in military courts. 
An additional 874 individuals will undergo military trials for criminal charges, with 1,714 facing charges related to terrorism. 142 people have been arrested in protests calling for social demands, with 87 detained because of workers' protests, and 415 having been arrested in sectarian events. ${ }^{7}$

The numbers and categories above reflect the state's classifications, which Wiki Tharwa used to compile its data. However, it is important to emphasize the fluidity and malleability of the boundaries of these categories and of who is counted where for which legal and administrative regulatory purposes.

As I was finalizing these brief notes, there were some significant new developments. A court ruling in April declared the April 6 movement-which was among the key allies of the Mahalla labor protesters - an illegal organization. Key revolutionary figures who have supported the calls for labor rights, dignity, and freedom have been sentenced to between two and fifteen years in prison. Workers protesting at their factories in Suez, Helwan, and Mahalla, to name only a few towns, have been violently attacked by military forces, their worksites besieged, and their leaders detained and prosecuted. Street vendors were rounded up on June 12 in a "cleansing campaign" waged by the municipal governments and security forces of many cities and towns throughout the country. The legality of independent syndicates was challenged in court, and a labor union law was issued that includes regressive and constraining clauses that do not allow for any meaningful representation of workers. A national minimum wage has become a practical impossibility given the financial constraints faced by the regime, while legal challenges to private investment-related rulings and decrees were eliminated. A new investment law contains a variety of loopholes, thus legally sanctioning corrupt practices. And the list goes on! Much as the attacks on laboring people continue, so their struggle remains undiminished. And they are still waiting, but not silently or passively. Rather, as Marx once said, "People make history under conditions not of their own making." And making history they are actually doing, while also remaking the conditions in which their struggles unfold. And they are still waiting...

\section{NOTES}

1. "PM Outlines Cabinet's Pledges, Calls for End of Strikes," Mada Masr, March 2, 2014, available at http://www.madamasr.com/content/pm-outlines-cabinet-pledges (accessed March $3,2014)$. Calls by public figures and TV anchors to stop protests "for the love of Egypt" proliferated and became a predominant media campaign that traversed the public and private media channels. (See, for instance, "For the Love of Egypt: To Strike or Donate," Mada Masr, March 11, 2014, available at http://www.madamasr.com/content/love-egypt-stike-donate (accessed April 2, 2014).

2. Mahalla is one of the main centers of the Egyptian textile industry. For years, workers at the various spinning companies demanded better wages and improved working conditions in addition to a share of profits and changes to managerial structures that were alleged to be steeped in corruption. In 2008, workers' calls for protests at the Misr Spinning Company were taken up by youth activists and, within a short span of time, "[a] Facebook group supporting the Mahalla workers and calling for a general strike in solidarity gained around 70,000 
members. On April 6, 2008, the actual strike in Mahalla was aborted by the police, but their attack on demonstrators touched off a near-insurrection in the town." Anne Alexander, "The Gravedigger of Dictatorship," Socialist Review (2011), available at http://www.socialistreview. org.uk/article/php?articlenumber=11580 (accessed on March 19, 2013).

3. See, for instance, Joel Benin, "Egyptian Workers and January 25th: A Social Movement in Historical Context," Social Research 79 (2012): 323-48; Anne Alexander, "Leadership and Collective Action in the Egyptian Trade Unions," Work Employment \& Society 24 (2010): 241-59; Asef Bayat, Life as Politics: How Ordinary People Change the Middle East (Stanford, CA: 2009); Rabab El-Mahdi, "Labor Protests in Egypt: Causes and Meaning," Review of African Political Economy 38 (2011): 387-402.

4. Hisham Sallam, "Striking Back at Egyptian Workers," Midan Masr, May 4, 2012; http://www.midanmasr.com/en/article.aspx?ArticleID=137 (accessed on May 5, 2012).

5. Kadeh is a campaign initiated by a group of young men and women who had initially held orthodox Islamic tendencies and later attempted to rework their ideologies and strategies by incorporating leftist ideas into their mode of operation and thinking. Their appearance in Cairo was primarily in the form of stencils with the name Kadeh that were sprayed on the walls of different buildings in various neighborhoods. They attempt to propose alternatives to classical left organizing and relationships to labor movements in the country.

6. Namir Galal, "The Closure of 4500 Factories over Two Years," AlMasry AlYoum, April 28, 2013, available at www.almsryalyoum.com/node/1695316 (accessed on May 1, 2013).

7. Wiki Thawra Report on the Detained and prosecuted, available at http://wikithawra. wordpress.com/2014/01/09/sisi-mansour-detainees/ (accessed May 25, 2014). 